\title{
IDEIAS NO LUGAR: SeNHORA, De José De AlenCAR
}

(MIS)PLACED IDEAS:

SENHORA, BY JOSÉ DE ALENCAR

Lúcia Granja

ORCID 0000-0002-2695-5345

Lilian Tigre Lima

ORCID 0000-0003-0012-9544

Universidade Estadual Paulista - UNESP

Sáo José do Rio Preto, SP, Brasil

\section{Resumo}

Este artigo estabelece um debate com "As ideias fora do lugar", de Roberto Schwarz, partindo da análise do romance Senhora, de José de Alencar. Sáo discutidas algumas implicaçóes e consequências teórico-críticas do método dialético aplicado à análise da literatura, buscando-se matizar a leitura de que o romance de José de Alencar não teria sido capaz de explorar, em âmbito formal, as potencialidades estruturantes do conteúdo social representado. Por um diálogo com a rigidez do olhar macrossociológico, e elegendo o mesmo método comparativo com as soluçôes encontradas por Machado de Assis em Helena (1876), Memórias Póstumas de Brás Cubas (1881) e Dom Casmurro (1899), este artigo propóe que, em Senhora, as ideias não estão "fora do lugar", mas ocupam o seu lugar, em uma estrutura socioeconômica em transição.

Palavras-chave: José de Alencar, Senhora, Machado de Assis, ideias fora do lugar, outro lugar das ideias.

\section{Abstract}

This article establishes a debate with Roberto Schwarz's concept of "misplaced ideas", stemming from the analysis of the novel Senhora, by José de Alencar. Some implications and theoretical-critical consequences of the dialectical method applied to the analysis of literature are discussed, in order to clarify the reading that José de Alencar's novel would not have been able to explore, in a formal context, the structuring potentialities of the represented social content. Through a dialogue with the rigidity of

\section{Resumé}

L'article établit un dialogue avec "As ideias fora do lugar" ("Les idées déplacées") à partir de l'analyse du roman Senhora, de José de Alencar, il souligne les implications et conséquences théoriques et critiques de la méthode dialectique appliquée à l'analyse de la littérature pour atténuer le jugement qui pèse sur la lecture du roman de José de Alencar. De fait, l'auteur n'aurait pas pu travailler, dans un contexte formel, les potentialités structurantes $\mathrm{du}$ contenu social représenté. A partir de la rigidité du regard macrosociologique et 
the macrosociological approach, and choosing the same comparative method with the solutions found by Machado de Assis in Helena (1876), Memórias Póstumas de Brás Cubas (1881) and Dom Casmurro (1899), this article proposes that, in Senhora, the ideas are not "misplaced," but occupying their place in a socioeconomic structure in transition.

Keywords: José de Alencar, Senhora, Machado de Assis, miplaced ideas, another place for ideas. de la méthode comparative de Schwarz (ou les solutions trouvées par Machado de Assis dans Helena, 1876, Mémoires posthumes de Brás Cubas, 1881 et Dom Camurro, 1899), cet article montre que dans le roman Senhora, les idées ne sont pas déplacées, mais occupent leur place dans une structure socio-économique de transition.

Mots-clés: José de Alencar, Senhora, Machado de Assis, les idées déplacées, autre place des idées.

Publicado há mais de quatro décadas, o ensaio "As ideias fora do lugar", de Roberto Schwarz, é ainda um terreno de fértil debate. Ao longo do tempo, foi se tornando aparente que essa voz desconfia da ilusão ideológica de superação do "atraso" e/ou do subdesenvolvimento, em função do chamado "milagre econômico" nos anos 1970, o período mais duro da repressão política instaurada no Brasil com a Ditadura Civil-Militar (1964-1989). Naquele horizonte produtivo para o imaginário social e, ao mesmo tempo, agônico para os intelectuais de esquerda, evidenciava-se a contradição produzida pela convivência inquietante da escravidáo com as ideias liberais no Brasil e reforçava-se a resistência à ingênua euforia em torno da "modernização conservadora". Nesse quadro geral, as "ideias fora do lugar" extrapolam a análise de questôes literárias e talvez por isso, ao longo do tempo, tenham-se validado, sobretudo, como interpretação do Brasil.

Entendida como "importação de ideias" ou, ainda, como "cópia de modelos externos", a suposta condição dissonante do liberalismo no Brasil e sua implicação no âmbito da cultura e da literatura estáo diretamente ligadas à teoria da dependência, que, formulada no campo da sociologia, tem seus pressupostos pautados em questóes de ordem econômica. Para os intelectuais da teoria da dependência, as condiçóes de desenvolvimento, de subdesenvolvimento e de não desenvolvimento dos países não seriam etapas de um processo linear nem temporário, mas, ao contrário, condiçôes estruturais indispensáveis para a própria manutenção do sistema capitalista internacional. Parte desse sistema, a América Latina, enquanto periferia das economias desenvolvidas, ocuparia, nesse processo, uma posição impreterivelmente dependente de desenvolvimento (CARDOSO; FALLETO, 1973). 
Incorporando o debate sobre a dependência econômica ao campo cultural e literário, Roberto Schwarz afirma que os impasses em torno do local e do global no caso latino-americano se configuram a partir da suposta "contradição entre a realidade nacional e o prestígio ideológico dos países que nos servem de modelo", contradição que, por sua vez, constituiria dado revelador do "caráter imitativo de nossa vida cultural" (SCHWARZ, 1987, p. 30). De acordo com a perspectiva schwarziana, as ideias importadas do centro, tais quais suas formas estéticas tradicionais, deveriam adquirir novas configuraçóes na periferia, tendo em vista suas peculiaridades. A forma importada deveria, portanto, ajustar-se à cor local e produzir novos significados, muitas vezes contrários ao modelo, sem, com isso, abrir mão da relação dialética com a literatura mundial, em especial a europeia, que constitui nossa principal matriz literária no século XIX.

Não é novidade dizer que foi em Machado de Assis que o crítico encontrou a plena realização do quadro acima descrito. Redesenhando a trajetória dos passos que dera Antonio Candido e, consequentemente, tomando a rigor o método crítico da "redução estrutural" (CANDIDO, 1976), Roberto Schwarz (1977), em análise dos primeiros romances de Machado de Assis, constrói o percurso de um escritor em busca de uma forma narrativa inovadora. Segundo o crítico, o autor das Memórias Póstumas de Brás Cubas teria sido aquele que, destoando de seus compatriotas contemporâneos, registrou importante virada na prosa de ficção brasileira, concedendo potência estruturante às relaçóes sociais brasileiras e fazendo com que essas engendrassem nova forma para o romance (SCHWARZ, 1990). Na outra ponta de destaque da prosa de ficção brasileira da época, ao contrário do que fez Machado, José de Alencar não teria sido capaz, ao adotar a estrutura tradicional do romance realista europeu, de reiterar em nível formal os impasses decorrentes da presença do ideário liberal europeu em um país cuja base econômica ainda mantinha relaçóes com escravismo e práticas clientelistas.

É válido ressaltar, contudo, que, embora considerado o principal discípulo de Antonio Candido e continuador de seu projeto de análise da formação do romance no Brasil, Roberto Schwarz apresenta certas divergências ideológicas, ainda que não evidentes, em relação ao "patriarca" (MELO, 2014, p. 405). Dessa perspectiva, se, por um lado, Candido, nutrido de seu socialismo otimista, demonstra certo entusiasmo em relaçáo às possibilidades transformadoras do quadro social brasileiro, em Schwarz "há o pessimismo frankfurtiano, isto é, um socialismo já sem redenção e a certeza de que o Brasil só integra a modernidade pelas portas do fundo" (MELO, 2014, p. 413). Crítico da mitologia do progresso, Schwarz, portanto, jamais apostou na "modernização à brasileira" como chave para a superação do "atraso", uma vez que, para o crítico, tal condiçấo seria inerente a uma sociedade cuja "má 
formação" se deu pela coexistência "disparatada" entre a prática escravista e a retórica iluminista.

A partir daí, apesar das afinidades metodológicas, Schwarz radicaliza o modelo crítico pensado por Antonio Candido, colocando-se em um ângulo teórico mais apertado, no qual parecem indelevelmente ligados "prognóstico sombrio" (MELO, 2014, p. 419) e rigidez do método. Isso porque, à medida que o primeiro, concebendo a obra de arte em sua autonomia, parte da fatura do texto para a compreensáo do modo como o externo é tornado interno, o crítico machadiano, analisando profundamente a mesma fatura, avalia os componentes da realidade social como determinantes para o movimento narrativo. Em outros termos, Schwarz, diferente de Candido, ao adotar uma visão que estreita conjuntura socioeconômica e seu contexto ideológico, náo se permite nenhuma flexibilização da estrutura, o que acaba por colidir com questóes relativas ao andamento dos processos históricos, ou mesmo culturais, como veremos no romance Senhora. No que se refere ao âmbito cultural, a perspectiva schwarziana impóe alguns problemas para críticos fixados a outros parâmetros ideológicos.

No caso de Alfredo Bosi, reconsiderando o que ele chama de "três versōes" registradas pela crítica em relação ao narrador das Memórias Póstumas (2006, p. 302), o intelectual afirma que, dentre as leituras centradas no tipo social de Brás Cubas, a de Schwarz é a mais extremada, revelando-se "um princípio doutrinariamente reducionista" (BOSI, 2006, p. 304). Ao identificar os traços de pensamento do narrador, bem como a configuração formal da obra, com a ideologia de um sujeito burguês pertencente à sociedade brasileira escravista e patriarcal, Schwarz teria "subordinado à situação local tanto os traços formais como os existenciais, objetos específicos das visadas anteriores" (BOSI, 2006, p. 303). Nesse sentido,o "nó problemático" que caracterizaria o método crítico de Roberto Schwarz seria sua orientação unilateral, segundo a qual o espaço e a classe social configurariam elementos determinantes para o esquema narrativo (BOSI, 2006, p. 304). Enquanto isso, para Bosi, seria possível identificar nas Memórias Póstumas de Brás Cubas a presença de uma "consciência mutável" (BOSI, 2006, p. 309), isso é, a do "eu" tipo social vivo e a do "eu" defunto (BOSI, 2006, p. 291), o que mostraria a força do narrador machadiano, ligada não apenas à sua potencialidade mimética, mas também aos impasses dessa consciência bivalente, cujos modos de pensar e de viver, quando colocados em situação de "auto-análise moral", às vezes concessiva e condescendente, revelam traços de uma "psicologia 'realista' universalizada" (BOSI, 2006, p. 287). Dessa análise de uma personagem que figura o caráter humano, pode-se ampliar a compreensão de pequenas nuances histórico-sociais, que ficam esmaecidas, por exemplo, no quadro fixo do intelectual marxista, adversário de Bosi nos estudos machadianos. Se o Brás Cubas de Bosi foi 
"homem", e, por exemplo, desejou com intençóes infames uma mulher, o machismo renitente da sociedade brasileira é um comportamento cultural que atravessa classes e gêneros na História.

Nem marxista nem existencialista, porém mais afinada com a primeira do que com a segunda, uma terceira leitura importante nos estudos em torno da construção de um "Machado de Assis realista" (GUIMARÁES, 2017, p. 20) é aquela proposta por John Gledson. Também preocupado com os modos de representação dos processos sociais e históricos na escrita machadiana, o crítico inglês, segundo Schwarz (1999, p. 106), teria registrado contribuiçôes importantes a essa corrente de análise, sendo a primeira delas a atenção às obras e aos gêneros, em geral, ignorados pela crítica (SCHWARZ, 1999, p. 106-107). Ainda, conforme aponta John Gledson, para a compreensão da obra machadiana, "as explicaçôes filosóficas ou a experimentação narrativa, quando encaradas em si mesmas, são instrumentos pouco eficazes" (GLEDSON, 1986, p. 16). Haveria em Machado de Assis um "quadro realista extraordinariamente multifacetado", no qual se entrecruzam "vida psicológica, social, religiosa, política e ideológica” (GLEDSON, 1986, p. 15), além de uma habilidade singular para a criaçáo de conjuntos artísticos significativos, dentro de um "projeto" intencionalmente elaborado pelo autor (GLEDSON, 1986, p. 17).

Se, por um lado, a leitura proposta por Gledson lhe rendeu duras críticas por subordinar a configuração da obra machadiana às "intençôes" do escritor, a perspectiva assumida pelo crítico inglês abre caminho para um entendimento mais amplo da ficção machadiana, olhada pela perspectiva realista. Ultrapassando fronteiras de classe, além de sugestóes psicológicas e existenciais, a genialidade da ficção machadiana, segundo Gledson, estaria no modo como as obras capturam momentos particulares da História social e política do Brasil, no século XIX, desvendando verdades históricas profundas. É a atenção a essas nuances históricas, passadas despercebidas pelas leituras de Schwarz e outros, que, segundo Gledson (1986, p. 19), permite situar a experimentação machadiana num "quadro convincente e coerente" da História do Brasil do século XIX, e compreendê-la, não como "causa", mas como "efeito" da interpretação que Machado de Assis fez do seu tempo e espaço. Essa singularidade do olhar machadiano, segundo Gledson, pressupóe a sensibilidade e intuição de quem soube flagrar momentos particulares do desenvolvimento social e político do Brasil, traduzindo-os em seu projeto ficcional, antes mesmo que tais acontecimentos tivessem sido consolidados como fatos históricos, conforme explica Guimarães (2017, p. 247-248). A garantia de que essa interpretaçáo de Gledson náo é anacrônica seria o fato de Machado de Assis ter sido um homem profundamente enraizado em seu tempo, do qual teve compreensão privilegiada. 
A partir daí, o método proposto por Gledson, ao analisar as obras em função do momento específico em que se situam os seus enredos, interessa à medida que, quando estendido para o romance Senhora, faz com que as ideias e o romance de Alencar entrem no lugar. Se, para Gledson, o projeto machadiano foi muito além do retrato objetivo da realidade à qual pertenceu, ele se configurou como um realismo ao mesmo tempo "enganoso" e "alegórico", no sentido de uma interpretação crítica e ampla do processo político e social brasileiro do século XIX. Esse "pensamento histórico" (GLEDSON, 1991, p. 8; GUIMARÁES, 2017, p. 234), que constitui a sensibilidade e intuição do escritor sobre seu tempo, também está presente no Alencar de Senhora, que teria percebido o momento de transição sociopolítica em que se situava o país, fazendo-o sentir no entrecho do romance. Portanto, um movimento de desobstrução da ideia crítica que se fixou ao último romance de Alencar consiste em repensar o lugar da narrativa no quadro histórico da sociedade brasileira da segunda metade do século XIX.

De acordo com Roberto Schwarz (1977), como se sabe, dado o problema da harmonia entre a composição interna da obra e o tecido social representado, Senhora seria uma espécie de tradução "mal resolvida" das ideias do liberalismo europeu, posto que no Brasil dominasse "o fato 'impolítico e abominável' da escravidáo” (SCHWARZ, 1977, p. 13). Como uma das consequências, nas relaçôes sociais o favor era "nossa mediação quase universal" (SCHWARZ, 1977, p. 16) e gerava um quadro de exceção. Para o crítico, "adotar o romance era acatar também a sua maneira de tratar as ideologias" (SCHWARZ, 1977, p. 29) e a ideologia do favor daria, pois, margem à arbitrariedade, que, por sua vez, seria incompatível com as tramas extremadas próprias do Realismo de tipo romântico (SCHWARZ, 1977, p. 32). Problematizando não o tema em si mas a forma que carrega o tema, Schwarz afirma que a obra de José de Alencar, embora capaz de inspirar ainda hoje, não foi propriamente bem-sucedida; foi, ao contrário, "descalibrada" e "boba" em muitos aspectos (SCHWARZ, 1977, p. 31). Diferente do que fez Machado de Assis, o escritor cearense teria tematizado a contradição sem, contudo, reiterar esse impasse em nível formal, o que lhe teria rendido um realismo ao mesmo tempo inconsistente e incompatível com as aparências locais (SCHWARZ, 1977, p. 33).

O olhar de John Gledson sobre Machado de Assis pode resgatar Senhora de uma condenação tão rija, pois permite que se matizem as cores com que se constrói a metáfora que dá conta da estrutura do romance, considerando que a própria superestrutura social não é tão inelástica quanto parece, bem como não o é a própria infraestrutura. Desse modo, embora os dois escritores, Alencar e Machado, tomem por matéria literária os mesmos temas, assentados sobre a mesma ideologia, o Brasil sobre o qual fala Alencar não é exatamente 
o mesmo sobre o qual fala Machado. Segundo Candido, a maestria desse está na fecundação da fórmula do romance românico refletido e na destruição da verossimilhança em nome da unidade representativa (CANDIDO, 1959, p. 118). Já de acordo com Schwarz, o pecado daquele está na tematização do ideário burguês nos moldes do Realismo de influência romântica (SCHWARZ, 1977, p. 32). No entanto, é necessário ter em vista que, enquanto o autor de Helena (1876), das Memórias Póstumas de Brás Cubas (1880) e de Dom Casmurro (1899) fala de um Brasil em que a escravidão, apesar lei de 1831, é ainda uma prática escandalosa, o autor de Senhora (1875), por sua vez, fala de um Brasil em que os debates sobre a abolição, assinada poucos anos depois, já haviam sido, em muito, avançados.

De acordo com Sidney Chalhoub (2012), a lei de 7 de novembro de 1831, que tratava da proibição do tráfico transatlântico de escravos, é exemplo antigo da farsa de que se transformou a memória do processo de abolição da escravatura no Brasil. Isso porque, só entre 1840 e 1850, duas décadas seguintes à promulgação da chamada "lei para inglês ver", mais de 750 mil negros teriam sido introduzidos no país ilegalmente ${ }^{1}$, num ritmo que concorre nas mesmas proporçóes com o período anterior ao decreto. Articulada pela elite política, a "Lei Eusébio de Queirós”, de 1850, por sua vez, mais do que reprimir o tráfico, conforme a pressão inglesa, foi definida com o propósito de calar sobre a decisão anterior, minimizando as responsabilidades dos fazendeiros sobre a posse de escravos comprados ilegalmente.

Se o tráfico ilegal permaneceu ainda por muitos anos, favorecido pela frouxidão da fiscalização de documentos de propriedade escrava, foi, sobretudo, na década de 1870 , que as discussóes em torno da abolição tomaram fôlego no país, atingindo as esferas política, intelectual e social, tendo havido transformaçóes significativas no tratamento da questão, que incluem a instauração da "Lei do Ventre Livre", em 1871, que libertava todos os nascidos a partir daquela data. Segundo Chalhoub, embora fosse mais uma obra conservadora, cujo objetivo era garantir a indenização dos senhores $^{2}$, o texto é resposta ao clima de abolição que então dominava o país. Eleito deputado estadual do Ceará pelo Partido Conservador, entre os anos

1 De acordo com Chalhoub (1990), esses negros, assim como seus descendentes, foram mantidos como propriedade escrava ilegal durante décadas, conforme é exemplo a escrava Beatriz, que, de acordo com sua matrícula, tem, em 1887, 51 anos de idade, tendo nascido, portanto, em 1836, 5 anos após a lei de proibiçẫo (In: CHALHOUB, S. Visóes da liberdade: uma história das ultimas décadas da escravidão na corte. São Paulo: Companhia das Letras, 1990).

2 No parágrafo $1^{\circ}$ do Artigo $1^{\circ}$ dessa lei, lê-se que "Os ditos filhos menores ficarão em poder ou sob a autoridade dos senhores de suas mães, os quais terão a obrigação de criá-los e tratá-los até a idade de oito anos completos. Chegando o filho da escrava a esta idade, o senhor da mãe terá opção, ou de receber o Estado a indenizaçáo de $600 \$ 000$ réis, ou de utilizar-se dos serviços do menor até a idade de 21 anos completos. No primeiro caso, o Governo receberá menor e lhe dará destino, em conformidade da presente lei (...)". 
1861 e 1877, Ministro do Império entre 1868 e 1870 e candidato a Senador de sua terra natal em 1868 (BROCA, 1965, p. 24-27), o autor de Senhora acompanhou de perto as projeçóes que se faziam sobre o fim da escravidão no país. Os debates sobre escravidão são, pois, peça-chave para se pensar a situação brasileira e as transformaçóes em torno das relaçôes produtivas e financeiras, estando essas últimas na ordem do dia para modernização de um Brasil pós-escravista.

Situando seus enredos sobretudo na primeira metade do XIX, Machado de Assis teria projetado neles a sua crítica à contradição no seio da família patriarcal e católica, também escravista, de modo que, levada às últimas consequências, a ironia machadiana parece compreender a falência do sistema paternalista e mesmo da ideologia burguesa: se, por um lado, Helena (1876) tematiza a violência por trás da ideologia senhorial, cuja moral, ao invés de coibir, realça a arbitrariedade, por outro lado, Brás Cubas não transmite a nenhuma criatura o legado da nossa miséria, e o filho-família, em Dom Casmurro (1899), casa-se com a moça pobre de Matacavalos.

Tal e qual Machado, em Senhora, Alencar busca testar situações da sociedade no escape àquela ordem social rígida, situando o enredo contemporaneamente ao período de publicação (em um dos bailes, Aurélia atravessa o saláo pelos braços do Barão do T., herói da Guerra do Paraguai). Ao contrário de Helena, herdeira bastarda quando o romance se inicia em 1850 , a trama alencariana se concentra no poder efetivamente assumido por Aurélia (o poder de Helena reside nas entrelinhas de suas açóes), apesar de a nova senhora também ser uma herdeira bastarda. Ambos os exemplos familiares questionam o sistema patriarcal, mas em fases diferentes dele. Fazendo da exceção sua matéria romanesca, o autor de Senhora oferece à protagonista uma solução individual frente à rigidez das determinaçóes sociais, no quadro socioeconômico de modernização das relaçóes entre dinheiro e propriedade de meados dos anos 1870. Não é apenas o acaso da sorte que está por detrás da independência financeira de Aurélia, mas a própria alienação das relaçóes regidas por contratos, a partir de uma perspectiva burguesa e liberal.

Embora Alencar resvale, por meio do romance realista, nas contradiçóes apontadas por Schwarz, seu trabalho distingue-se do que faz Machado de Assis, à medida que situa sua história em uma sociedade de transição entre a velha lógica escravista, no seio da qual habita a contradição, e o Brasil que tenta se abrir para o que já era e viria a ser, mesmo no pós-escravismo, o lugar da convivência pacífica por abafamento entre relaçóes autoritárias de trabalho e a aparente ordem liberal. Se é evidente, por exemplo, em Senhora, que a escravidão tem seus dias contados, a lógica do romance realista burguês se justifica melhor nesse texto do que nas sociedades figuradas por Machado de Assis: Bentinho tem 15 anos em 1857; Brás Cubas nasceu em 1805 e expirou 
em 1869; o reconhecimento de Helena dá-se em $1850^{3}$, quando ela tem 16 para 17 anos. Todas essas personagens convivem com uma indeterminação geral em relação à situação da escravidão, embora, em termos legais, sua expansão e continuidade estivessem falsamente controladas. Dessa forma, pode-se imaginar que essas famílias dos romances machadianos haviam sido estruturadas de maneira mais rígida do que as novas possibilidades que se abriam em meados dos anos 1870, em que o poder do dinheiro, exaustivamente representado em Senhora, alinha-se a tempos de profundas modificaçōes históricas.

Na visão de Schwarz (1977, p. 33), o tom de Senhora é mais “desafogado na periferia do que no centro", o que quer dizer que há uma complicação realista maior na relação personagens centrais e secundárias do que na das centrais entre si. Mas, alternativamente, considera-se que isso se deva justamente ao fato de José de Alencar estar lidando com duas geraçóes distintas, que, por sua vez, correspondem a momentos diferentes da história brasileira. Espécies de "predecessores" de José Dias (o agregado por excelência), Dona Firmina Mascarenhas, uma senhora de "gordura semi-secular", o Sr. Lemos, um "velho de pequena estatura", e o Sr. Camargo, um fazendeiro já no fim da vida, são contemporâneos à vida que viveu Brás Cubas e fazem parte desse período em que a escravidão, e suas contradiçóes, ainda se faz fortemente presente e indefinida. Mas, ao contrário dessas figuras caricaturais do arbítrio (SCHWARZ, 1977, p. 16), que seriam representaçóes desse "Brasil velho" ainda presente, a jovem Aurélia Camargo, de 18 anos, e Fernando Seixas, "um moço que ainda não chegou aos trinta anos" (ALENCAR, 1973, p. 36), corresponderiam a esse tom mais "complexo" da trama justamente porque eles fazem parte de um Brasil em gestação, que aos poucos se abre para uma nova ordem social e econômica. Ao enfatizar, portanto, a subserviência dos "agregados" aos caprichos da protagonista, Alencar não se debruça nas relaçóes de favor em si, mas chama a atenção para esse momento tênue, no qual se confundem, ainda mais, um resto de violência advinda da vontade senhorial com a violência da prática liberal cada vez mais desabrida, ambas testemunhas de uma modernização conservadora, resistente à mudança, que a história ainda não apagou.

Personagem que foge ao padrão hegemônico culturalmente estabelecido e aceito como normal às mulheres da elite carioca da segunda metade do século XIX, o modo como se comporta Aurélia no romance ajuda a compreender a

3 Segundo Marta de Senna, nas notas em hipertexto à edição eletrônica do romance, que consta do site www.machadodeassis.net, quase todas as ediçōes posteriores à primeira (inclusive a segunda, publicada ainda em vida de Machado de Assis, em 1905) trazem a data de 1859 na primeira linha do romance. No entanto, isso é muito provavelmente uma erro tipográfico (troca de " 0 " por " 9 "), visto haver um desacordo com o enredo do romance, já que, no capítulo XI, de Helena, um desenho que oferece ao irmão cerca de três meses depois de ter ido morar com a família porta a data de 25 de julho de 1850 . 
complexidade histórica do que teria sido esse período de transição no Brasil, marcado pela abolição da escravatura e abertura ao capital. Socialmente condenada à posição de subalternidade, a protagonista escapa às amarras do sistema paternalista por dois caminhos: primeiro por ter sido educada como uma garota pobre, livre de certas convençóes sociais criadas em torno da vida de determinada classe; segundo, e decorrente do primeiro, por se tornar rica, sendo independente de espírito, além de ter uma postura crítica em relação aos usos e costumes e, portanto, detentora de todo o poder que o dinheiro lhe confere (e conferia à sociedade capitalista de ideologia liberal). Salva, portanto, pela liberdade da "miséria e da opulência" (ALENCAR, 1973, p. 29), o poder de Aurélia advém desses dois extremos libertadores.

A partir daí, é possível considerar não só o romance mas também Aurélia como alegoria dessa mudança. Dividida entre a infância simples em Santa Tereza e as passagens triunfais pelos salóes fluminenses, a protagonista, a quem a vida imprimira "uma expressão fria, pausada e inflexível" (ALENCAR, 1973, p. 26), demonstra total consciência dessa transição de uma vida a outra, bem como da dimensão que o poder do dinheiro lhe outorga. Assim, dividida entre a aspiração romântica e a racionalização da ótica capitalista, Aurélia seria uma espécie de "monstro disforme" da Literatura Brasileira, cuja composição, nem romântica nem realista, é imagem da sociedade a que pertence.

Tâo contraditório quanto a protagonista, Fernando Seixas também encarna no romance a ideia de transição. "Filho de um empregado público e órfăo aos dezoito anos" (ALENCAR, 1973, p. 41), Seixas era um tipo de "trabalhador" do universo liberal. Seguindo os passos do pai, o protagonista iniciou sua carreira como funcionário público, encontrando mais tarde na imprensa a sua maior vocaçấo. Embora viesse a se tornar "um dos escritores mais elegantes do jornalismo fluminense” (ALENCAR, 1973, p. 41), Seixas, devido à recusa da mãe, jamais contribuiu com as despesas da casa. $\mathrm{O}$ patrimônio herdado do pai, depois da liquidação de uma hipoteca e de dívidas miúdas, rendeu à família doze contos de réis e quatro escravos. A soma, embora importante, servia a produzir juros semestrais, os quais não aumentavam o montante, pois deles vivia a família, além de alugarem dois escravos e de a mãe e as irmãs de Seixas fazerem algumas costuras. Como se vê, os lucros com investimentos financeiros não são imensos, e também essa família vive em uma situaçáo intermediária entre a possibilidade de desfrutar das comodidades do capitalismo financeiro, dos rendimentos advindos de propriedades (alugar escravos), e estar abrigada em um certo universo de trabalho, artesanal e, portanto, pré-capitalista.

Nesse caso, mesmo colocado no mercado de trabalho, Seixas paira acima das preocupações inerentes a esse mundo. A vida de sua família, extremamente modesta, contrasta com sua vida pessoal, pois, sem a independência de espírito 
de Aurélia, a mãe de Seixas, afirmando a organização familiar patriarcal, preocupava-se com que o filho fizesse sempre a melhor figura na sociedade, que "o seu Fernandinho se vestisse no rigor da moda e com a maior elegância; que em vez de ficar em casa aborrecido, procurasse os divertimentos e a conveniência dos camaradas" (ALENCAR, 1973, p. 42). Assim, enquanto sua mãe e suas irmâs passavam o serão na sala de jantar, o dândi, que tinha na sociedade a representação de um moço rico, frequentava os altos círculos da Corte.

Com a maioridade, coube a Seixas a gestão do patrimônio conquistado pela família. Dos $8.500 \$ 000$ (oito contos e quinhentos mil réis) de rendimento acumulados de seu ofício, Seixas dava à família $1.800 \$ 000$ (um conto e oitocentos mil réis), ficando para os seus "gastos de representação" $6.700 \$ 000$ (seis contos e setecentos mil réis). Acontece que "as despesas de ostentação com sua pessoa unicamente, absorviam-lhe todo o rendimento anual, além dos créditos suplementares" (ALENCAR, 1973, p. 123). Esse contraste mirabolante da convivência do luxo e da pobreza não fala de outra coisa a não ser da violência "implacável dessa ordem social metálica" (DE MARCO, 1986, p. 72), regida pelas leis do mercado, de tal modo que a palavra "dinheiro" é grafada quase cinquenta vezes no romance.

Pensados por José de Alencar através da contradição escandalosa entre riqueza e pobreza, tanto em Aurélia como em Seixas o luxo mais absurdo convive com a extrema modéstia. Se, no caso de Seixas, o chapéu fabricado em Paris, os charutos de Havana e os perfumes franceses e ingleses contrastam com a pobreza da habitaçáo em que vivia a personagem na rua do Hospício, no caso de Aurélia o "lampiáo mortiço" da humilde salinha de Santa Tereza contrasta com "a grande lâmpada a gás" do aposento da protagonista nas Laranjeiras. Privilégio de uma burguesia já enriquecida, o serviço de iluminação a gás, nesse período, é sinal importante da chegada das novas tecnologias da era capitalista no quadro da cidade do Rio de Janeiro nos meados da década de 1870. Pintado com tinta forte, os quadros ambíguos que constituem a casa e a vida social de Fernando Seixas, bem como o passado pobre e o presente rico de Aurélia, são moldados, portanto, de modo a realçar os impasses de uma sociedade em transição.

Nesse sentido, os protagonistas desta história constituem verdadeira metonímia de uma parcela da sociedade em que a ordem patriarcal convive com as ideias liberais, já em fase de franco "progresso". Assim, embora pareça que Alencar está tratando de uma sociedade aparentemente engessada, cujas possibilidades de variação seriam quase nulas, o romancista está testando a transiçáo dessa sociedade para o sistema capitalista. A partir daí, as ideias presentes em Senhora estariam, portanto, não tão "fora do lugar", mas, emprestando uma expressáo que serve a outros fins, no "entre-lugar" (SANTIAGO, 1978) de uma estrutura em movimento. 
Para reforçar a sutileza da constataçáo, conforme mostra Maria Sylva de Carvalho Franco (1976), nem o fato da escravidão nem a relação do favor impediram que o Brasil do século XIX estivesse integrado ao círculo internacional de acumulação capitalista. Ou seja, embora essas práticas, a priori, inviabilizassem as ideias do liberalismo europeu, esse pensamento não estava presente no Brasil somente no âmbito da imaginação; estavam presentes tanto no plano econômico, por exemplo, através do lucro dos senhores de escravos angariado pela produçáo agrícola, como no plano político, através da projeção da ideologia liberal por trás da Independência. Acontece que, por aqui, tudo isso convivia com um longo período de indeterminação da escravidão, o que tornava aquela sociedade ainda mais complexa, porém náo aquém do sistema.

Marcada por uma economia dependente do latifúndio monocultor, de base eminentemente escravista, a vida social brasileira do século XIX estaria ancorada na ordem do sistema paternalista. "Política de domínio na qual a vontade senhorial é inviolável, e na qual os trabalhadores e os subordinados em geral só podem se posicionar como dependentes em relação a essa vontade soberana" (CHALHOUB, 2003, p. 47), o paternalismo teria imposto à sociedade brasileira oitocentista uma realidade pouco variável, cuja rigidez impossibilitaria a constituiçáo de uma sociedade de classes. No entanto, de acordo com Sidney Chalhoub (2003), é preciso considerar que essa acepção de paternalismo, tal como se apresenta, só é possível no seio da ideologia senhorial. Isso porque, conforme têm demonstrado trabalhos recentes, oriundos de uma nova perspectiva historiográfica, "a vigência de uma ideologia não significa a inexistência de solidariedades horizontais e, por conseguinte, de antagonismos sociais" (CHALHOUB, 2003, p. 48). Em outros termos, a aparente hegemonia cultural e política do sistema paternalista no Brasil não impediu que aquela sociedade encontrasse meios de escapar àquele sistema rígido.

De grande contribuição para a historiografia brasileira, o trabalho de Peter Eisenberg (1972) mostra como teria sido esse processo de transição do trabalho escravo para o livre no Brasil. Tomando por base o período de 1840 e 1910, o historiador chama a atenção, a partir de análise empírica, para as implicaçóes sociais e econômicas da convergência dos processos de abolição da escravatura, adoção de novas técnicas de produção de açúcar e introdução generalizada do trabalho livre no país. Tendo por "homens esquecidos", os trabalhadores livres, bem como os escravos forros e cativos, Eisenberg (1989) mostra que, mesmo na escravidão, os senhores de escravos já se valiam de estratégias próprias do sistema capitalista para lucrar, como é exemplo o arrendamento de terras por escravos e pagamento de tributo anual aos seus senhores. 
Espécie de flâneur ${ }^{4}$ da cidade do Rio de Janeiro do Segundo Império, como o sujeito que transita pelas Passagens da Paris do século XIX, José de Alencar passeia pela pesquisa de seus caracteres e, para pensar nos termos de Schwarz, combina, na história dos indivíduos, matéria literária (superestrutura) com as contradições advindas de uma ordem socioeconômica em transformação (infraestrutura). Em outras palavras, em Senhora, Alencar teria construído caricaturas, uma espécie de ironia por hipérbole, criando personagens que encarnam contradiçóes descomunais, como forma de compor o romance realista brasileiro. Se, em Machado de Assis, o romance brasileiro finalmente encarna a "síntese perfeita", denunciando, através da forma literária (a mudança do ângulo narrativo, agora conduzido por um "defunto autor"), o absurdo da vontade senhorial, pintado através do autoritarismo arbitrário de Brás Cubas, essa "atitude paródica", vista, talvez, como a única forma de se falar daquela estrutura social em transição, está também presente no último romance de Alencar.

\footnotetext{
4 "Sabeis o que é a flânerie? É o passeio ao ar livre, feito lenta e vagarosamente, conversando ou cismando, contemplando a beleza natural ou a beleza da arte; variando a cada momento de aspectos e de impressóes. O companheiro inseparável do homem quando flana é o charuto; o da senhora é o seu buquê de flores. O que há de mais encantador e de mais apreciável na flânerie é que ela não produz unicamente o movimento material, mas também o exercício moral. Tudo no homem passeia: o corpo e a alma, os olhos e a imaginação. Tudo se agita; porém é uma agitação doce e calma, que excita o espírito e a fantasia, e provoca deliciosas emoçôes. A cidade do Rio de Janeiro, com seu belo céu de azul e sua natureza táo rica, com a beleza de seus panoramas e de seus graciosos arrabaldes, oferece muitos desses pontos de reunião, onde todas as tardes, quando quebrasse a força do sol, a boa sociedade poderia ir passar alguns instantes numa reuniáo agradável, num círculo de amigos e conhecidos, sem etiquetas e cerimônias, com toda a liberdade do passeio, e ao mesmo tempo com todo o encanto de uma grande reuniấo. (ALENCAR, J. Ao correr da pena. In: Obra completa. Rio de Janeiro: Aguilar, 1960. p. 666, v. IV).”
} 


\section{Referências}

ALENCAR, J. de. Senhora. São Paulo: Melhoramentos, 1973 [Reprodução do texto da $1^{a}$ edição, publicada por B. L. Garnier, Rio de Janeiro, 1875].

BENJAMIN, W. Passagens. Belo Horizonte/São Paulo: Ed. UFMG/Imprensa Oficial do Est. de São Paulo, 2006.

BOSI, Alfredo. Dialética da colonização. 4. ed. São Paulo: Companhia das Letras, 2001. . Ideologia e contraideologia. São Paulo: Companhia das Letras, 2010.

. Brás Cubas em três versões. Teresa, revista de Literatura Brasileira, São Paulo, 2006, p. 279-317.

BROCA, B. Introdução biográfica. In: ALENCAR, J. de. Iracema - lenda do Ceará. Rio de Janeiro: José Olympio. Edição do Centenário, 1965, p. 19-38.

CANDIDO, A. Formação da Literatura Brasileira (momentos decisivos). São Paulo: Livraria Martins editora, 1959.

. Literatura e sociedade: estudos de teoria e história literária. São Paulo: Editora Nacional, 1976.

CARDOSO, F. H.;FALETTO, E. Dependência e desenvolvimento na America Latina. Rio de Janeiro: Zahar, 1973.

CHALHOUB, S. Visóes da liberdade: uma história das ultimas décadas da escravidão na corte. São Paulo: Companhia das Letras, 1990.

. Machado de Assis: historiador. São Paulo: Companhia das Letras, 2003.

- A força da escravidão: ilegalidade e costume no Brasil oitocentista. São Paulo: Companhia das Letras, 2012.

DE MARCO, V. O império da cortesã: Lucíola, um perfil de mulher. São Paulo: Martins Fontes, 1986.

EISENBERG, P. Homens esquecidos: escravos e trabalhadores livres no Brasil, séculos XVIII e XIX. Campinas: Editora da UNICAMP, 1989.

FRANCO, M. S. de C. As ideias estão no lugar. Cadernos de debate, São Paulo, n.1, p. 61-64, 1976.

GLEDSON, J. Machado de Assis: ficção e história. Tradução de Sônia Coutinho. Rio de Janeiro: Paz e Terra, 1986.

- Machado de Assis: impostura e realismo - uma reinterpretação de Dom Casmurro. Tradução de Fernando Py. São Paulo: Companhia das Letras, 1991. 
GUIMARÁES, H. de S. Machado de Assis: o escritor que nos lêe - as figuras machadianas através das críticas e das polêmicas. São Paulo: Editora da UNESP, 2017.

SANTIAGO, Santiago. Uma literatura nos trópicos: ensaios sobre dependência cultural. Sáo Paulo: Editora Perspectiva, 1978.

SCHWARZ, R. Ao vencedor as batatas: forma literária e processo social nos inícios do romance brasileiro. São Paulo: Duas Cidades, 1977.

. A contribuição de John Gledson. Sequências brasileiras: ensaios. São Paulo: Companhia das Letras, 1999, p. 106-112.

. Um mestre na periferia do capitalismo: Machado de Assis. São Paulo: Duas Cidades, 1990.

. Nacional por subtração. Que horas são? São Paulo: Companhia das letras, 1987 , p. 29-48.

Lúcia Granja é professora de Literatura e Cultura Brasileiras na UNESP (campus de São José do Rio Preto), Livre-Docente em Literatura Brasileira pela UNESP (2016), Doutora em Teoria e História Literária pela UNICAMP (1997) e Mestre em Teoria e História Literária pela UNICAMP (1992). Realizou três estágios de pós-doutorado: PARIS/VERSAILLES (CHCSC, Université de Versailles à St. Quentin-en-Yvelines, 2012-2013); PARIS (Fondation Maison des Sciences de l'Homme/Université Paris VII, Denis Diderot, 2008); LISBOA: Universidade Nova de Lisboa/Instituto Camóes (1999). É bolsista de Produtividade em Pesquisa do CNPq e pesquisadora-associada ao Centre d'Histoire Culturelle des Sociétés Contemporaines, da Université de Versailles à St. Quentin-en-Yvelines (desde 2013) e ao Centre de recherches sur les pays lusophones, da Université Paris 3-Sorbonne Nouvelle (desde 2015).

E-mail: lucia.granja@unesp.br

Lilian Tigre Lima é Doutoranda em Letras pela Universidade Estadual Paulista Júlio de Mesquita Filho (UNESP), campus de São José do Rio Preto. Possui Mestrado em Letras - História, Cultura e Literatura e Graduação em Letras (Licenciatura) com habilitação em português e francês pela mesma instituição. Tem experiência na área de Letras, com ênfase em História Literária, atuando principalmente nos temas: História do livro e da edição, História do leitor e da leitura, Honoré de Balzac, José de Alencar, século XIX.

E-mail: liliandelima17@hotmail.com 